\title{
Erratum to: Recent Advances in Face Lift to Achieve Facial Balance
}

\author{
Velupillai Ilankovan ${ }^{1}$
}

Published online: 3 February 2017

(C) The Association of Oral and Maxillofacial Surgeons of India 2017

Erratum to: J. Maxillofac. Oral Surg. DOI 10.1007/s12663-016-0981-8

The corresponding author name was incorrect in published article. The correct author name should read as "Velupillai Ilankovan".

The original article has been updated accordingly.

The online version of the original article can be found under doi: 10.1007/s12663-016-0981-8.

Velupillai Ilankovan

velupillai.ilankovan@poole.nhs.uk

1 Department of Head and Neck Surgery, Poole Hospitals NHS

Trust, Longfleet Road, Poole BH15 2JB, UK 